\title{
Influences of $\mathrm{Y}_{2} \mathrm{O}_{3}$ Doping on Hydrogen Release Property of $\mathrm{LiAlH}_{4}$
}

\author{
Liu Shenglin', Ma Qiuhua², Zheng Xueping ${ }^{1}, \quad$ Feng Xin ${ }^{1}, \quad$ Xiao Guo , \\ Zheng Jiaojiao ${ }^{1}$ \\ ${ }^{1}$ Chang'an University, Xi'an 710061, China; ${ }^{2}$ Henan University of Technology, Zhengzhou 450001, China
}

\begin{abstract}
The dehydrogenation properties of $\mathrm{LiAlH}_{4}$ doped with $\mathrm{Y}_{2} \mathrm{O}_{3}$ were investigated by PCT (Pressure-CompositionTemperature) equipment. The results show that with the increase of amount of $\mathrm{Y}_{2} \mathrm{O}_{3}$, the dehydrogenation amount of $\mathrm{LiAlH}_{4}$ increases, however, when the doping amount reaches a certain value, the hydrogen release amount decreases with the increase of doping amount. Compared to the $\mathrm{LiAlH}_{4}$ sample, the dehydrogenation starting time of the samples doped with $\mathrm{Y}_{2} \mathrm{O}_{3}$ is significantly brought forward. In addition, it can be found that the dehydrogenation rates of all the doped samples are higher than that of the original sample. The change trends of the dehydrogenation rates of all the doped samples are similar in the whole dehydrogenation process, namely, with the extension of time, the dehydrogenation rates increase firstly, and then decrease gradually.
\end{abstract}

Key words: hydrogen release amount; hydrogen release rate; $\mathrm{LiAlH}_{4} ; \mathrm{Y}_{2} \mathrm{O}_{3}$

Since the energy crisis, the environmental pollution and the greenhouse effect have been caused by a large amount of energy consumption, people have been studying the efficient energy. Hydrogen is recognized as the ideal future energy due to high calorific value. In addition, hydrogen is a potential major alternative as an environment friendly energy carrier. Importantly, hydrogen is the most abundant element in the universe. It can be produced through water decomposition by solar energy, wind energy and geothermal energy and other natural energies, and it is an inexhaustible secondary energy ${ }^{[1-3]}$ which will be never used up. However, due to the lack of convenient and effective hydrogen storage materials and hydrogen storage technology, the application of hydrogen energy has been greatly hindered for a long time. Therefore, in order to realize the application of hydrogen as an energy carrier, the hydrogen storage problem must be solved. At present, for the researches on hydrogen storage materials there are mainly three kinds of categories: metal hydrogen storage materials, porous adsorption hydrogen storage materials and organic liquid hydrogen storage materials. Among them,

the hydrogen storage alloys attract more and more people's attention due to their high hydrogen storage capacity, no pollution, safety and reliablity. According to the different combination type, the hydrogen storage alloys can be divided into two categories: one is the metal hydride hydrogen storage alloy, the other is the complex hydride hydrogen storage alloy.

Compared with the metal hydride hydrogen storage alloy, the complex hydride hydrogen storage alloy has much higher hydrogen storage amount. For example: the hydrogen storage amounts of $\mathrm{NaAlH}_{4}$ and $\mathrm{LiAlH}_{4}$ have achieved $7.4 \mathrm{wt} \%$ and $10.5 \mathrm{wt} \%$, respectively. Up to now, a great deal of researches has focused on finding better catalysts. For example, Resan $\mathrm{M}^{[4]}$ and other scientists studied $\mathrm{TiH}_{2}, \mathrm{TiCl}_{3}, \mathrm{TiCl}_{4}, \mathrm{AlCl}_{3}, \mathrm{FeCl}_{3}, \mathrm{Fe}, \mathrm{Ni}, \mathrm{V}$, Ti and $\mathrm{C}$. In addition, some new catalysts were studied, such as $\mathrm{NH}_{4} \mathrm{Cl}^{[5]}, \mathrm{TiF}_{3}{ }^{[6]}$, nano fiber ${ }^{[7]}$, nano nickel ${ }^{[8]}, \mathrm{NH}_{3}{ }^{[9]}$ etc. In this work, the dehydrogenation properties of $\mathrm{LiAlH}_{4}$ doped with $\mathrm{Y}_{2} \mathrm{O}_{3}$ will be studied.

\section{Experiment}

Received date: March 18, 2013

Foundation item: National Natural Science Foundation of China (50806007); Central Key Projects of Scientific Research in Colleges and Universities Operating Costs (CHD2011ZD008)

Corresponding author: Liu Shenglin, Ph. D., Associate Professor, School of Materials Science and Engineering, Chang'an University, Xi'an 710061, P. R. China, E-mail: zxp2004b@aliyun.com

Copyright (c) 2014 Northwest Institute for Nonferrous Metal Research. Published by Elsevier BV. All rights reserved. 
$\mathrm{LiAlH}_{4}$ with purity $\geqq 93 \%$ was purchased from $\mathrm{J} \& \mathrm{~K}$ Chemical Ltd. $\mathrm{NaAlH}_{4}$ was used as the received with no additional purification. The main purpose of this experiment is to study the influences of different rare earth compounds on the hydrogen release property of $\mathrm{LiAlH}_{4}$. The selected rare earth compound was $\mathrm{Y}_{2} \mathrm{O}_{3}$. The ball milling device adopted is planetary ball mill, all samples were milled for $1 \mathrm{~h}$ at a gyration rate of $200 \mathrm{r} / \mathrm{min}$, and the ratio of ball to powder was 22:1. In order to prevent the samples from oxidation, the loading of the samples and sampling process were carried out in a glove box filled with argon. The hydrogen release properties of the samples were tested by PCT (Pressure-Composition-Temperature) equipment. Firstly, the samples were heated to $200{ }^{\circ} \mathrm{C}$, and then kept under this temperature for $150 \mathrm{~min}$. The doping amounts (mol\%) of the dopants were 0.5, 1, 2, 3, 4, 5 and 6 . The microstructure was analyzed by SEM (scanning electron microscope)

\section{Results and Discussion}

Fig. 1 shows the curves of the dehydrogenation amount vs the time of the $\mathrm{LiAlH}_{4}$ samples doped with $0.5 \mathrm{~mol} \% \sim 6$ mol\% $\mathrm{Y}_{2} \mathrm{O}_{3}$ and the pure $\mathrm{LiAlH}_{4}$ sample. It can be seen that all the samples show obvious two-step decomposition. At the same time, the experimental results indicate that the sample doped with $1 \mathrm{~mol} \% \mathrm{Y}_{2} \mathrm{O}_{3}$ has the largest amount of hydrogen release, while the sample doped with $5 \mathrm{~mol} \%$ $\mathrm{Y}_{2} \mathrm{O}_{3}$ has the smallest amount of hydrogen release. And as the doping amount increases from $1 \mathrm{~mol} \%$ to $5 \mathrm{~mol} \%$, the dehydrogenation amount of the samples decreases gradually, but the dehydrogenation amount of the sample doped with 6 mol\% $\mathrm{Y}_{2} \mathrm{O}_{3}$ increases, which is same to the dehydrogenation amount of the sample doped with3 mol\% $\mathrm{Y}_{2} \mathrm{O}_{3}$. The final dehydrogenation amount of the $\mathrm{LiAlH}_{4}$ samples doped with $0.5 \mathrm{~mol} \%, 1 \mathrm{~mol} \%$, and $2 \mathrm{~mol} \%$ is larger than that of the original sample under the same conditions, while the final dehydrogenation amounts (mol\%) of the samples doped the 3, 4, 5, 6 are smaller than that of the original sample. In addition, from the slope of the curves in Fig. 1, it can be seen that, the dehydrogenation rate of the doped samples are higher than that of the original sample.

Fig.2 show the changing relations between the maximum dehydrogenation amount and the doping amount. It is easy to see that only the dehydrogenation amounts of the samples doped with $0.5 \mathrm{~mol} \%$ and $1 \mathrm{~mol} \%$ are larger than that of the original sample, when the doping amount is among 1 mol\% 5 mol\%, with the increase of the $\mathrm{Y}_{2} \mathrm{O}_{3}$ doping amount, the dehydrogenation amount of the samples decreases gradually. The dehydrogenation amount of the sample doped with $1 \mathrm{~mol} \% \mathrm{Y}_{2} \mathrm{O}_{3}$ is the largest, while the dehydrogenation amount of the sample doped with $5 \mathrm{~mol} \%$ $\mathrm{Y}_{2} \mathrm{O}_{3}$ is the least.

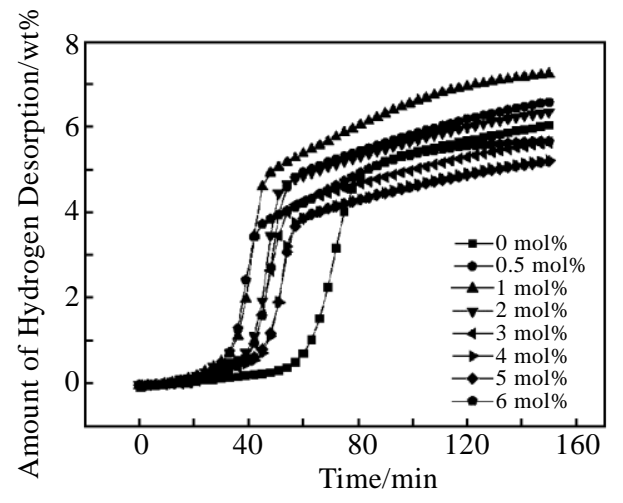

Fig.1 Curves of the dehydrogenation amount vs the time of the $\mathrm{LiAlH}_{4}$ samples doped with 0 mol\% 6 mol\% $\mathrm{Y}_{2} \mathrm{O}_{3}$

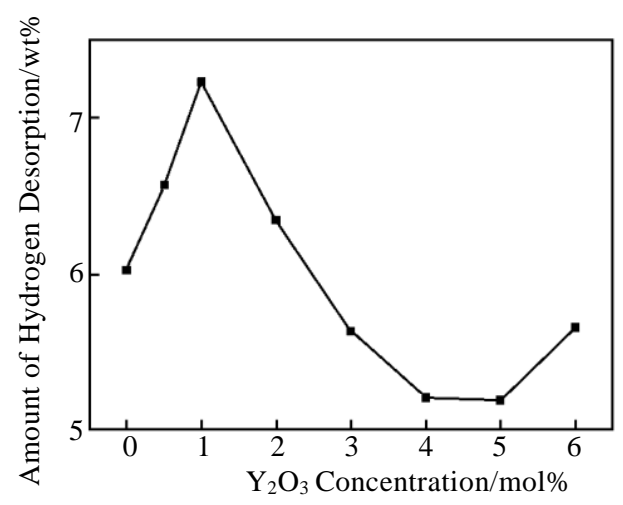

Fig.2 Curve of the dehydrogenation amount of the $\mathrm{LiAlH}_{4}$ samples doped with 0 mol\% $6 \mathrm{~mol}^{2} \mathrm{Y}_{2} \mathrm{O}_{3}$ and the concentration of $\mathrm{Y}_{2} \mathrm{O}_{3}$

Fig.3 shows the relational curves between the dehydrogenation rate and the dehydrogenation time of the samples doped with $\mathrm{Y}_{2} \mathrm{O}_{3}$. It can be seen that the dehydrogenation rate of the samples doped with $\mathrm{Y}_{2} \mathrm{O}_{3}$ are higher than that of the original sample, and dehydrogenation starting time of the doped samples is significantly earlier, namely maximum peaks of the dehydrogenation speed of the samples doped with 0.5 mol\% $6 \mathrm{~mol} \% \mathrm{Y}_{2} \mathrm{O}_{3}$ appear earlier than that of the original sample. Furthermore, the original sample and the samples doped with $0.5 \mathrm{~mol} \% \sim 6 \mathrm{~mol} \% \quad \mathrm{Y}_{2} \mathrm{O}_{3}$ all show, with the extension of time, the dehydrogenation rate increases firstly, when the dehydrogenation rate is increased to a certain value, it begins to decrease. The dehydrogenation rate of the sample doped with $2 \mathrm{~mol} \% \mathrm{Y}_{2} \mathrm{O}_{3}$ is the highest.

Fig.4 gives the amount of dehydrogenation of the samples doped with $0.5 \mathrm{~mol} \% \sim 6 \mathrm{~mol}^{\%} \mathrm{Y}_{2} \mathrm{O}_{3}$ in the first and second steps. It is obvious that the dehydrogenation amount of the sample doped with $1 \mathrm{~mol} \% \mathrm{Y}_{2} \mathrm{O}_{3}$ is the largest in the first and second steps. With the increase of amount of $\mathrm{Y}_{2} \mathrm{O}_{3}$, except for the sample doped with $6 \mathrm{~mol} \% \quad \mathrm{Y}_{2} \mathrm{O}_{3}$, the dehydrogenation amounts of the samples present firstly an increase and then a decrease. 


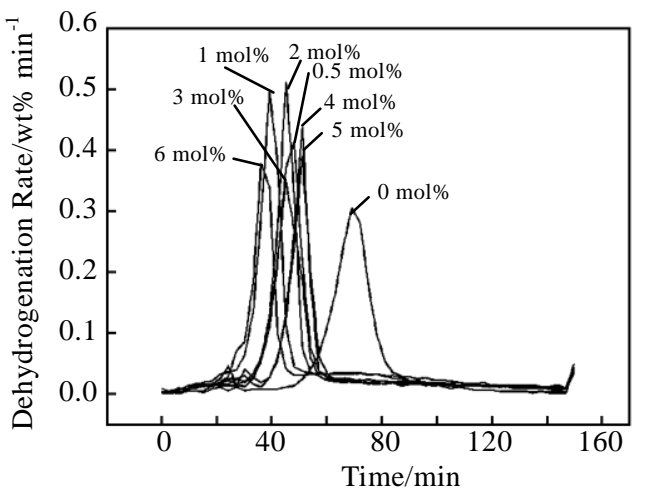

Fig.3 Curves of the dehydrogenation rate and the time of the $\mathrm{LiAlH}_{4}$ samples doped with $0 \mathrm{~mol} \% \sim 6 \mathrm{~mol}_{\%} \mathrm{Y}_{2} \mathrm{O}_{3}$

In this part work, the microstructure of the samples doped with $\mathrm{Y}_{2} \mathrm{O}_{3}$ was analyzed. Fig.5 gives the SEM images of $\mathrm{LiAlH}_{4}$ sample and the samples doped with $\mathrm{Y}_{2} \mathrm{O}_{3}$. It can be found that the microstructure of all samples present a kind of flocculent structure. In addition, a lot of pores are found on the surface of the powder of all samples. We consider these pores may be left by overflowing hydrogen when the samples were milled.

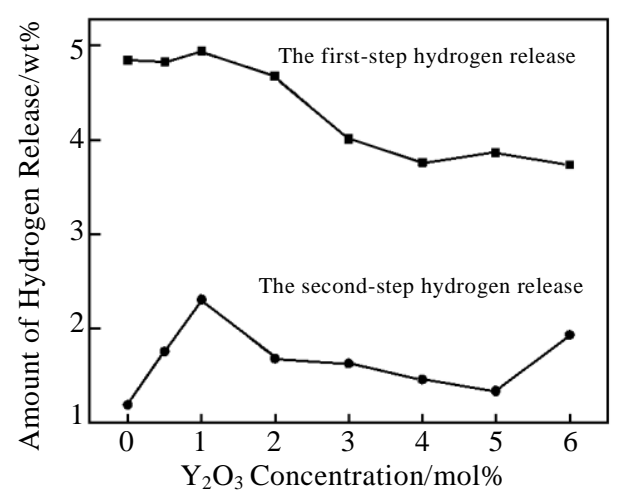

Fig.4 Dehydrogenation amount of the $\mathrm{LiAlH}_{4}$ samples doped with $0 \mathrm{~mol} \% \sim 6 \mathrm{~mol} \% \mathrm{Y}_{2} \mathrm{O}_{3}$ in the first and second steps

Table 1 compares the dehydrogenation amount and maximum dehydrogenation rate of the $\mathrm{LiAlH}_{4}$ samples doped with $\mathrm{Y}_{2} \mathrm{O}_{3}$. Among the samples doped with $\mathrm{Y}_{2} \mathrm{O}_{3}$, the sample doped with 1 mol\% $\quad \mathrm{Y}_{2} \mathrm{O}_{3}$ has the largest dehydrogenation amount of $7.23 \mathrm{wt} \%$, while the sample doped with $2 \mathrm{~mol} \%$ has the maximum dehydrogenation rate of $0.51 \mathrm{wt} \% / \mathrm{min}$.

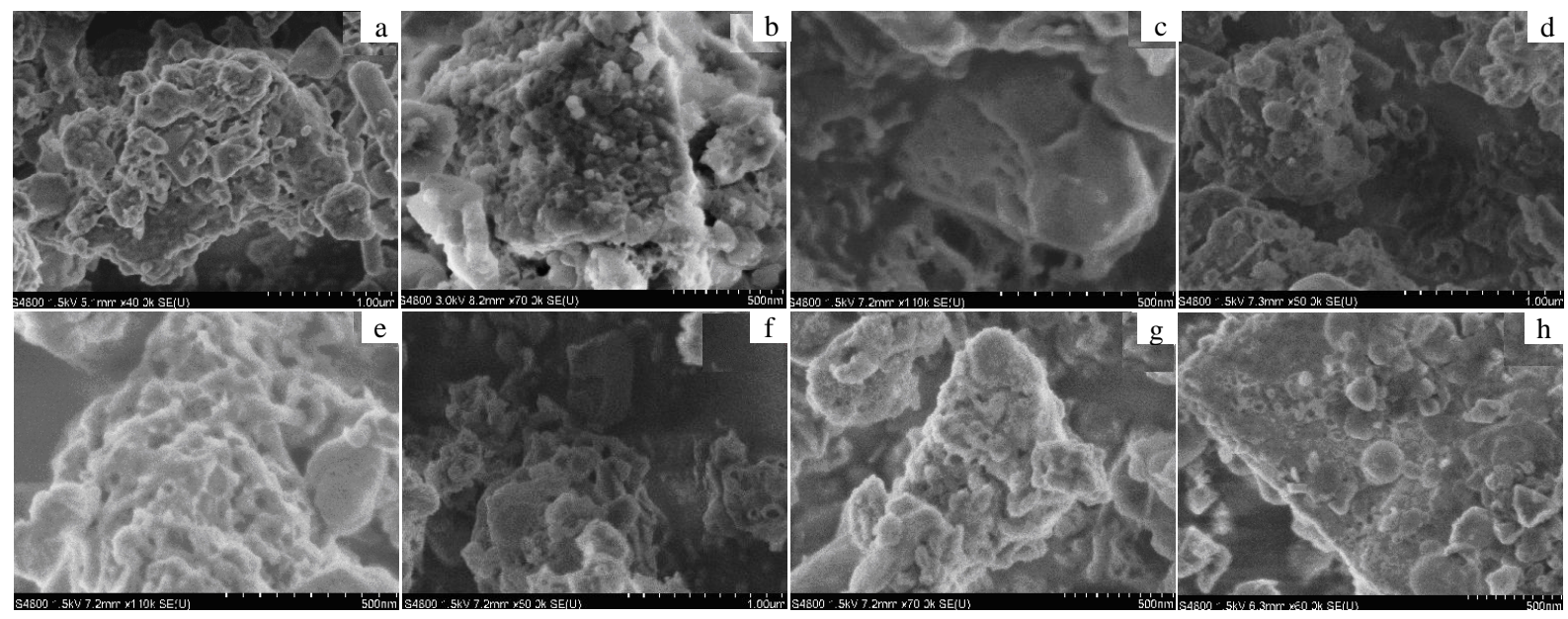

Fig.5 SEM images of the samples doped with different amount of $\mathrm{Y}_{2} \mathrm{O}_{3}$ : (a) $0 \mathrm{~mol} \%$, (b) $0.5 \mathrm{~mol} \%$, (c) $1 \mathrm{~mol} \%$, (d) $2 \mathrm{~mol} \%$, (e) $3 \mathrm{~mol} \%$, (f) $4 \mathrm{~mol} \%$, (g) $5 \mathrm{~mol} \%$, and (h) $6 \mathrm{~mol} \%$

Table 1 Dehydrogenation amount and maximum hydrogen release rate of the samples doped with different amount of $\mathrm{Y}_{2} \mathrm{O}_{3}$

\begin{tabular}{ccc}
\hline $\begin{array}{c}\mathrm{Y}_{2} \mathrm{O}_{3} \text { doped/ } \\
\text { mol\% }\end{array}$ & $\begin{array}{c}\text { Dehydrogenation } \\
\text { amount/wt } \%\end{array}$ & $\begin{array}{c}\text { Maximum hydrogen } \\
\text { release rate/wt\% } \mathrm{min}^{-1}\end{array}$ \\
\hline 0.5 & 6.57 & 0.41 \\
1 & 7.23 & 0.50 \\
2 & 6.35 & 0.51 \\
3 & 5.63 & 0.35 \\
4 & 5.21 & 0.44 \\
5 & 5.19 & 0.39 \\
6 & 5.66 & 0.38 \\
0 & 6.03 & 0.31 \\
\hline
\end{tabular}

\section{Conclusions}

1) With the increase of doping amount, the dehydrogenation amount of $\mathrm{LiAlH}_{4}$ increases, however, when the doping amount reaches a certain value, the dehydrogenation amount begins to decrease.

2) Compared to the $\mathrm{LiAlH}_{4}$ sample, the dehydrogenation starting time of the samples doped with $\mathrm{Y}_{2} \mathrm{O}_{3}$ is significantly brought forward.

3) The dehydrogenation rates of all the doped samples are higher than that of the original sample. And, the change 
of the dehydrogenation rates of all the doped samples are similar in the whole dehydrogenation process, namely, with the extension of time, the dehydrogenation rates increase rapidly, and then decrease gradually.

\section{References}

1 Luo W, Ronnebro E. J Alloy Compd[J], 2005, 404-406: 392

2 Johnston B, Mgyo M C, Khare A. Technovation[J], 2005, 25: 569

3 Sherif S A, Barbir F, Veziroglu T N. The Electricity Journal[J], 2005, 18(6): 62

4 Resan M, Hampton M D, Lomness J K et al. Int J Hydrogen
Energy[J], 2005, 30: 1413

5 Huajun Zhang, Yook Si Loo, Hans Geerlings et al. Int J Hydrogen Energy[J], 2010, 35: 176

6 Liu Shusheng, Sun Lixian, Zhang Yao et al. Int J Hydrogen Energy[J], 2009, 34: 8079

7 Hima Kumara L, Viswanathan B, Srinivasa Murthy S. Int J Hydrogen Energy[J], 2008, 33: 366

8 Robert A Varin, Leszek Zbroniec, Tomasz Czujko et al. Int J Hydrogen Energy[J], 2011, 36: 1167

9 Weifang Luo, Donald Cowgill, Ken Stewart et al. J Alloy Compd $[\mathrm{J}], 2010,497: 17$

\title{
掺杂 $\mathrm{Y}_{2} \mathrm{O}_{3}$ 对 $\mathrm{LiAlH}_{4}$ 放氢性能的影响
}

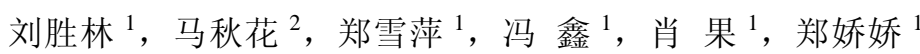 \\ (1. 长安大学, 陕西 西安 710063)
}

(2. 河南工业大学, 河南 郑州 450001)

\begin{abstract}
摘 要: 主要通过 $\mathrm{PCT}$ 设备研究了掺杂 $\mathrm{Y}_{2} \mathrm{O}_{3}$ 的 $\mathrm{LiAlH}_{4}$ 试样的放氢性能。结果显示, 随着 $\mathrm{Y}_{2} \mathrm{O}_{3}$ 掺杂量的增加, $\mathrm{LiAlH}_{4}$ 的放氢量增 加, 然而, 当掺杂量达到某一值时, $\mathrm{LiAlH}_{4}$ 的放氢量随着掺杂量的增加而降低。和 $\mathrm{LiAlH}_{4}$ 原样相比, 掺杂 $\mathrm{Y}_{2} \mathrm{O}_{3}$ 的试样初始放氢 时间提前。此外, 关于 $\mathrm{Y}_{2} \mathrm{O}_{3}$ 对 $\mathrm{LiAlH}_{4}$ 放氢速率影响的研究还发现, 所有掺杂试样的放氢速率都比未掺杂原样的放氢速率快。并且 所有掺杂试样的放氢速率的变化趋势都是相似的, 即：随着时间的延长，放氢速率快速增大之后逐步降低。
\end{abstract}

关键词: 放氢量; 放氢速率; $\mathrm{LiAlH}_{4} ; \mathrm{Y}_{2} \mathrm{O}_{3}$

作者简介: 刘胜林, 男, 1975 年生, 博士, 副教授, 长安大学材料科学与工程学院, 陕西 西安 710063, E-mail: zxp2004b@aliyun.com 